\title{
LEGISLATIVE AND JURISPRUDENTIAL GUIDELINES CONCERNING PUBLIC JUDICIAL AID. JURISPRUDENCE OF THE CONSTITUTIONAL COURT OF ROMANIA RELEVANT IN THE FIELD
}

DOI: $10.47743 /$ rdc-2018-2-0002

Anca-Jeanina NITT $\breve{A}^{1}$

\section{Abstract}

This article aims to bring to the forefront the issue of public legal aid by carrying out an analysis that combines the theoretical perspective with the jurisprudential one. It presents the normative framework, the doctrinal approaches, the legal practice in the field, with emphasis on the legal provision that generated non-unitary practice. The article presents the attempts to harmonize the legal practice, displaying the opinions expressed during the Meetings of the representatives of the Superior Council of Magistracy with the presidents of the civil department of the High Court of Cassation and Justice and the courts of appeal.

Taking into account that public legal aid is one of the prerequisites for free access to justice - fundamental law, constitutionally guaranteed, it is particularly important to present the case law of the Romanian Constitutional Court in the matter, focusing on the acceptance of ECHR case law within the constitutional control of the public legal aid framework regulation Government Emergency Ordinance no. 51/2008.

Keywords: access to justice; public legal aid; constitutionality control; non-unitary legal practice

\section{Introductive considerations}

In any democratic state, access to justice is a fundamental right of any person, regardless of their social or financial position.

In European human rights law, the notion of access to justice is enshrined in Articles 6 and 13 of the Convention for the Protection of Human Rights and Fundamental Freedoms and Article 47 in the Charter of Fundamental Rights of the

\footnotetext{
${ }^{1}$ University Lecturer, “Ovidius” University of Constanța, The Faculty of Law and Administrative Science.
} 


\section{Anca-Jeanina NIȚĂ}

European Union, which guarantees the right to a fair trial and an effective remedy, in accordance with the interpretation given by the European Court of Human Rights (EC) and, respectively, the Court of Justice of the European Union (C.J.U.E.).

The right of access to justice - a notion whose existence was determined by the pretorian way, in the C.E.D.O. practice, being consecrated in the case Golder vs. United Kingdom $^{2}$ case, is a guarantee which gives expression to the institutional mechanisms (of substantive and procedural law) to be cultivated in order to strengthen the unswerving faith in justice - a fundamental value of the trust of the citizen in the rule of law.

The only way to guarantee the effectiveness of the right of access to justice is to implement a functional system of legal assistance, a system enshrined in Directive 2003/8/EC to improve access to justice in cross-border disputes - transposed into the national legislation by the Government Emergency Ordinance number 51/2008 on public judicial aid ${ }^{3}$.

Public judicial aid - as a form of assistance granted by the state from public funds to those who do not dispose of enough financial resources to face the expenses of a trial, represents an additional guarantee of the exercise of the right of access to a court under equal conditions.

As suggested and argued in the specialized doctrine, public judicial assistance is one of the prerequisites for the effectiveness of free, equal and fair access to justice: "free" that is without financial obstacles; "equal", that is without discriminations in relation with the material state; "fair", i.e. on the platform of "equality of arms and procedural means"4.

\section{. Legislative and jurisprudential benchmarks}

\section{on public judicial assistance}

The right of access to justice is one of the constituent elements of the right to a fair trial, in addition to the CEDO jurisprudence, which is expressly regulated in our legal system, by article 21 of the Constitution ${ }^{5}$ and article 6 of Law number 304/2004 concerning judicial organization ${ }^{6}$.

\footnotetext{
2 CEDO Jurisprudence, case “Golder vs. United Kingdom” (notification number 4451/70), paragraph 33, material available online, at address: http://hudoc.echr.coe.int/eng?i=001-57496.

${ }^{3}$ Approved with modifications through Law number 193/2008, published in the Gazette of Romania, Part I, number 723 of October 24, 2008.

${ }^{4}$ I. Deleanu, Ajutorul public judiciar. Legislația europeană și română în materie, in Dreptul no. 8/2008, p. 17.

${ }^{5}$ Article 21 - with the marginal name "Free Access to Justice" disposes:

(1) Any person can address justice for the defence of its legitimate rights, freedoms and interests.

(2) No law can limit the exercise of this right.

(3) The parties are entitled to a fair trial and to the settlement of the cases within a reasonable time.

(4) The special administrative jurisdictions are facultative and gratuitous."

${ }^{6}$ Article 6 in Law number 304/2004: "(1) Anyone can address justice to defend their rights, freedoms and legitimate interests in exercising their right to a fair trial. (2) Access to justice cannot be limited".
}

\section{CONSTITUTIONAL LAW REVIEW}




\section{Legislative and jurisprudential guidelines concerning public judicial aid}

Judicial public assistance is a guarantee of the state social and social protection, provided by the state towards the citizen, the social character of the state being foreseen by article 1 paragraph (3) of the Constitution?

As mentioned, the Government Emergency Ordinance O.U.G number 51/2008 concerning public judicial assistance ${ }^{8}$ represents the transposition into national legislation of the Directive of the European Union Council 2003/8/CE of 27.01.2003 for the improvement of access to justice in cross-border disputes ${ }^{9}$ through the establishing of common minimum rules concerning the legal assistance granted in such litigation.

By adopting the Government Emergency Ordinance O.U.G. number 51/2008, which considers that access to justice - an expression of democratic principles in a rule of law and law supremacy state - must be effective and that the costs of a judicial procedure must not constitute an obstacle to seeking justice in order to achieve or defend of a right, justifying, in certain situations and conditions, a support from the state, from public financial resources, the Romanian State created an efficient mechanism, fully functional and is likely to meet the C.E.D.O. standard in matter of.

The purpose of this regulation is provided by article 1 of the Government Emergency Ordinance O.U.G. number 51/2008 and consist in "ensuring the right to a fair trial and guaranteeing equal access to justice, for the realization of legitimate rights or interests by judicial means, including for the enforcement of court rulings or other enforceable titles".

As regards the extent and scope of the Government Emergency Ordinance O.U.G. number $51 / 2008$, it is obvious - from the clear drafting of the provisions of articles 3 and 4 , that the normative act refers exclusively to the natural person who seeks public judicial assistance in civil (irrespective of the quality of the parties, whether professional or unprofessional), administrative, work and Social Security cases, as well as in other cases, with the exception of the criminal ones.

The forms in which the public judicial assistance car be granted are limitatively provided by article 6 in Government Emergency Ordinance O.U.G. number 51/2008, respectively: a) payment of the fee for representation, legal assistance and, where appropriate, defense through a lawyer appointed or elected, for the realization or protection of a right or legitimate interest in court or for the prevention of a dispute, hereinafter referred to as lawyer assistance; b) payment of the expert, translator or interpreter used during the trial, with the approval of the Court or of the authority with jurisdictional attributions, if this payment goes, according to law, to the person requesting public judicial assistance; c) payment of the bailiff's fee; d) exemptions, reductions, staggered payments or deferrals from the payment of legal fees provided by law, including those due in the forced execution stage".

\footnotetext{
${ }^{7}$ Article 1 paragraph 3 in the Constitution disposes: "Romania is a state of law, democratic and social in which all the rights and freedoms of citizens are supreme values and are guaranteed by the state."

${ }^{8}$ Published in the Official Gazette number 327/25.04.2008.

${ }^{9}$ Published in the Official Gazette of the European Union series L number 26 of January 31, 2003.
} 
The interpretation of article 6 letter d) in Government Emergency Ordinance OUG 51/2008 generated a non-unitary judicial practice, the controversy regarding the extent to which the application for public judicial assistance in the form of exemption/ reduction/postponement/scaling from the payment of the bail is or not admissible in relation to the drafting of the legal provision.

Some courts ${ }^{10}$ considered that the requests concerning the granting of the public judicial assistance in the form of exemption/reduction/postponement/scaling from the payment of the bail are inadmissible, as domestic law does not provide for the possibility of granting public judicial assistance for the payment of bail, and the right of access to justice is not breached, as long as the solution in the application for the suspension of forced execution dopes not prevent the substantive settlement of the right under analysis in the contestation of execution.

Other Courts ${ }^{11}$ admitted such applications, invoking the application with priority of the provisions of article 6 paragraph 1 in the Convention and/or invoking the fact that at point C3 letter e) of the annex to the Government Emergency Ordinance O.U.G. number $51 / 2008$ reference is made to the possibility of granting public support for the payment of the bail.

We support the reasoned opinion ${ }^{12}$ according to which the bail does not represent a form of public judicial assistance that can be granted according to the provisions of the Government Emergency Ordinance O.U.G. number 51/2008, since:

\footnotetext{
${ }^{10}$ Court of sector 3 Bucharest, the conclusion of 27.02.2014 (unpublished), pronounced in the file number $10367 / 301 / 2014$.

11 The court of sector 1 Bucharest, with the conclusion of 26.09 .2013 (unpublished), delivered in file number $37103 / 299 / 2013$, orders the reduction of the bail quantum, retaining that " although the claimant based its claim on the provisions of the Government Emergency Ordinance O.U.G. number 51/2008, this normative act does not contain any reference to the courts' possibility to pronounce themselves on the request of exemption/ reduction of the bail, which does not make these claims inadmissible, however, but the court is to proceed with the analysis of the application in the light of CEDO practice and fundamental human rights that should govern any analysis of a petition before a national court. Thus, article 403 paragraph (1) Code of civil procedure shows that the suspension of execution shall operate if a security is lodged in the amount fixed by the court, resulting that if the court can set the amount to be paid with this title, means that it can also order its reduction or even exemption from payment. Also, in support of the admissibility of this request, the provisions of article 21 of the Romanian Constitution are also retained, concerning the free access to justice and article 14 paragraph (1) thesis I in the International Pact on civil and political rights. In this sense is also the jurisprudence of the European Court of Human Rights, in the application of article 6 paragraph 1 in the Convention showing that any person has the right to a fair, public settlement, within a reasonable time of his case, by an independent and impartial court, legally constituted, that will decide on the breach of civil rights and obligations. The rejection by the national judicial bodies of the requests for the reduction or exemption from bail would be a violation of a fundamental component of the right to a fair trial: the right of access to a court of justice. (...) The court considers that the rejection of the request for the provisional suspension for failure to file bail would only deprive the claimant of the possibility to obtain the examination of the merits of the case and, therefore, of the right of access to a court, the very essence of the right of access to a court being affected".

${ }^{12}$ ) INM Opinion exposed in the "MINUTES of the meeting of the representatives of the Superior Council of Magistrates' Court with the presidents of the civil sections of the courts of appeal and If the High Court of Cassation and Justice Court of Appeal Iaşi, May 7-8, 2015" document available online at the address http://www.inmlex.ro/ fisiere/d_1164/Intalnirea\%20presedintilor\%20sectiilor\%20civile,\%20Iasi,\%207-8\%20mai\%202015.pdf.
}

CONSTITUTIONAL LAW REVIEW 


\section{Legislative and jurisprudential guidelines concerning public judicial aid}

- article 6 of Government Emergency Ordinance O.U.G. number 51/2008 lists the forms of public judicial aid, and the payment out of the public budget of the bail to be given in order to judge on the applications for the suspension of execution (forced) is not mentioned in the legal provisions specified;

- the argument of the mention referring to the bail, from point $\mathrm{C}$ letter $\mathrm{e}$ ) in the form-annex is not consistent given that, on the one side, the annex of a normative act cannot be interpreted beyond the limits traced by the content of this act (under this aspect, article 6 is, clearly, limitative in listing the forms of public judicial assistance, for the reason that the identification of the cases of allocation of budgetary resources could not be performed in a lenient manner, eventually left to the discretion of the authorities seized with the request for public judicial assistance), and, on the other side, the form-annex considers the request for public judicial assistance in other Member States of the European Union. Or, in the latter hypothesis, a rule of a Member State allowing EU citizens to have access to public judicial assistance cannot be ruled out de plano including in the form of bails relating to the applications of the suspension of enforcement; (...)

- if stamp duties imply that a community as a whole bears the cost of a trial that the individual cannot pay, the bail in the matter of the application to suspend the forced execution comes to guarantee, however to a limited extent, any damage devolving upon the creditor against whom the suspension measure would be disposed; by way of consequence, the exemption or the reduction of bail under the level provided by the law leads to a subsidy of the debtor not by the collectivity but by another person. Such subsidies, at least in the current state of the legislation and in relation with the phase of suspension of the forced execution related to the contestation of execution or of any other application concerning the forced execution, could represent, especially in the case of contestations which object can be evaluated in money, ordering the creditor to a disproportionate sacrifice.

The abovementioned normative act regulates in detail:

- the conditions that should be met to approve the aid (article $8^{13}$ and article $8 / 1^{14}$ );

\footnotetext{
13 Article 8 - the form modified by Law no. 251/2011: “(1) The public judicial aid in the forms provided by article 6 is meant for the persons whose net monthly average income per family member in the last two months prior to the application was below the level of 300 lei. In this case, the amounts constituting the public judicial aid are advanced fully by the state. (2) If the average net monthly income per family member in the last two months prior to the application is below the level of 600 lei, the amounts of money constituting public judicial aid are advanced by the state in a proportion of 50\%. (3) The public judicial aid can be also granted in other situation, proportionally with the claimant's needs, in the cases in which the costs, certain or estimated of the trial are likely to restrict effective access to justice, inclusively because of the differences of the cost of living between the member state where he/she has domicile or residence and the one in Romania".

${ }^{14}$ Article 8/1: "The public judicial aid is granted, according to the present emergency ordinance, independent of the applicant's material status, if a special law provides for the right to legal assistance or the right to free legal assistance as a protection measure, in consideration of special situations, as minority, handicap, a certain status and other of the same type. In this case, the public judicial assistance is granted without meeting the criteria foreseen at article 8, but only for the the defense or recognition of certain rights or interests resulting
}

STUDIES AND ARTICLES 
- the modalities of granting (article $7^{15}$ ) and extinguishing the public judicial assistance (article $10^{16}$ );

- the procedure of granting public judicial assistance in terms of the following elements: the aid application and the the supporting documents that must be annexed to it, the competent court and the appeal against the court's decision - the re-examination request ${ }^{17}$, the effects of the admission of the public judicial aid application.

The strictly personal nature of the right to public judicial assistance - detached from the interpretation of Article 10 of the Government Emergency Ordinance O.U.G. number $51 / 2008$, is also underlined in the case of procedural co-participation.

In the case of applications or actions jointly submitted by several persons, if the subject of the lawsuit is a common right or duty or if their rights or obligations have the same cause or whether between them there is a close connection, the judicial stamp duty is jointly and severally liable, as expressly provided through article 35 paragraph (1) of the Government Emergency Ordinance O.U.G. number 80/2013.

In the specialized doctrine it was stated that when the application has the same object or when the object of the application is a common right or obligation, but only one of the claimants is entitled to the granting of public legal aid in the form of exemption from the payment of the judicial stamp duty. In such a case, the effect of admitting the application for the public judicial assistance in the person of one of the claimants does not extend over the other co-participants, but on the contrary, they will be subject to the obligation to pay integrally the judicial stamp duty due $\mathrm{e}^{18}$.

However, the judicial practice did unanimously agree with the doctrine, with the outlining of two orientations ${ }^{19}$ :

or related to the particular situation that justified the recognition, by law, of the right to judicial assistance or free judicial assistance".

${ }^{15}$ Article 7: "Free judicial assistance can be granted, cumulatively, in any of the forms provided for at article 6, without exceeding, over a period of one year, the maximum amount equivalent to 12 gross national salaries at the level of the year in which the application for the grant was made".

16 Article 10: "The right to la public judicial assistance extinguishes through the death of the party or the improvement of his/her material condition up to a level allowing them to cope with the trial costs".

17 The High Court of Cassation and Justice decided that the re-examination request provided for by article 15 of the Government Emergency Ordinance O.U.G. number 51/2008 represents a special special appeal, withdrawal, the only one that can be exercised against the rejection of the application for public judicial assistance. the issues regarding the way of solving the request for granting the public judicial assistance cannot form the object of criticism through recourse remedies, as there is no right of option of the party in this matter. In this case, the Supreme Court dismissed the appeal against a decision taken by the Chamber of the Council to resolve the request for public judicial assistance. (Decision no. 429 of March 8, 2017 delivered in appeal by Civil Section I of the High Court of Cassation and Justice having as object the granting of public judicial assistance), available online on the site https://www.juridice.ro/520640/iccj-calea-de-atac-impotriva-solutionarii-cererii-deacordare-ajutorului-public-judiciar.html.

${ }^{18}$ G. Boroi ş.a., New Code of Civil Procedure. Comments on articles Vol. I Art. 1-526, Hamangiu Publishing House, Bucharest, 2013, p. 256

19 "MINUTES of the Meeting of the representatives of the Superior Council of the Magistracy with the presidents of the civil sections of the High Court of Cassation and Justice and the courts of appeal, May 11-12, 2017, Court of

CONSTITUTIONAL LAW REVIEW 


\section{Legislative and jurisprudential guidelines concerning public judicial aid}

In the majority opinion, it was considered that the exemption from the payment of the stamp duty concerns only the co-participant entitled to the granting of public judicial aid and who invested the court with such an application. The effects of admitting a request for public judicial assistance do not extend to co-claimants who have not formulate such an application or who, even if they formulated it, do not meet the the conditions for the granting of public judicial assistance, any of them being liable, as a result of solidarity, to the full payment of the judicial stamp duty established by the court. The failure to pay the judicial stamp duty by the coparticipants who do not benefit from public judicial assistance attracts partial cancellation of the request as far as they are concerned. In the hypotheses of compulsory procedural co-participation, the involvement in the process of the co-participants in respect of which operated the cancellation of the request for summons for failing to pay the court stamp duty will be made on the basis of the provisions of article 78 Code of civil procedure 2.

In the minority opinion, in view of the solidarity of the obligation to pay the stamp duty it was considered that the request for public judicial assistance cannot be admitted only in respect of one of the co-participants if the requirements of granting public judicial assistance are not fulfilled in the person of all the co-participants, hypothesis in which it is imperative to reject the request for public judicial assistance as unfounded.

As regards the appeal, the majority opinion is in the sense that when the appeal is promoted by two or more persons, and only one of them makes a request for public judicial aid in respect of the judicial stamp duty attached to the request of appeal, request that is admitted, the obligation to pay stamp duty goes to the other plaintiffs. If the latter do not pay the judicial stamp duty, the court of appeal will admit, through the conclusion, the exception of the non-stamping the appeal promoted by them, and, through the final decision settling the merits of the appeal, will cancel their appeal. Instead, the court of appeal will settle the appeal promoted by the claimant whose application for public judicial assistance was admitted. Also, after admitting, through the conclusion, the exception of not stamping the appeal promoted by the appellants who do not meet the conditions of not granting public judicial assistance and did not pay the judicial stamp duty, and up to the settlement of the appeal formulated by the one whose request for public judicial assistance was admitted, through the decision, the first coparticipants will continue to be cited in in their capacity of de appellants, in accordance with article 60 paragraph (2) Code of civil procedure.

Non-unitary judicial practice has also emerged in terms of resolving the issue of the possibility that the person meeting the conditions provided by the ordinance for the granting of public judicial assistance, should benefit from this right, in the circumstances in which the guilty conduct, which led to the suspension of the trial, is retained in their charge.

Appeal Bucharest" - document available online at the address http://www.inm-lex.ro/fisiere/d_1913/Minuta\% 20intalnire\%20sectii\%20civile\%2011\%2012\%20mai\%202017.pdf.

STUDIES AND ARTICLES 


\section{Anca-Jeanina NIȚĂ}

In accordance with the provisions of article 6 letter d) of the Government Emergency Ordinance O.U.G. number 51/2008 concerning public judicial assistance in civil matter, it can be granted in the form of the exemption, reduction, rescheduling or postponement of the legal fees provided for by law, including of those due in the forced execution phase. The above-mentioned legal text does not make any distinction as to the scope of public judicial aid in relation to the category of applications subject to stamping. Therefore, irrespective of whether a procedural fault can be withheld in charge of the party for formulating a certain request, it can benefit from public judicial assistance, if it meets the conditions foreseen by the ordinance for its granting. As such, even if the suspension of the case was due to the party's attitude, the latter can benefit from public judicial aid in respect of the judicial stamp duty relating to the request for public judicial aid ${ }^{20}$.

The "special law concerning public judicial assistance" refers to article 90 paragraph 1 of the Code of civil procedure ${ }^{21}$.

The legal provision mentioned regulates distinctly the judicial assistance granted to the natural persons (paragraph 4).

Judicial assistance to individuals includes: a) the granting of exemptions, reductions, rescheduling or deferrals for the payment of judicial fees provided by law; b) defense and free assistance through a lawyer appointed by the bar; c) any other means provided by law (paragraphs 1-3).

Legal entities can only benefit from facilities in the form of discounts, staggered payments or deferrals for the payment of stamp duty fees due for actions and claims brought before the courts, in accordance with the provisions of article 42 paragraphs (2)-(4) in Emergency Government Ordinance number 80/2013 concerning the judicial stamp duties.

\footnotetext{
${ }^{20}$ MINUTES OF THE MEETING OF THE PRESIDENTS OF THE COURTS OF APPEAL CIVIL SECTIONS October 13-14, 2016, Court of Appeal Cluj, document available online at the address http://www.inmlex.ro/fisiere/ d_1713/Minuta\%20intalnire\%20sectii\%20civile\%20Cluj\%20Napoca\%20octombrie\%202016.pdf.

${ }^{21}$ Article 90 code of civil procedure orders:

(1) A person who is unable to meet the costs of initiating and supporting a civil process without jeopardizing his/her own maintenance or his/her family may receive legal assistance, in accordance with the special law concerning public judicial assistance.

(2) Judicial assistance includes:

a) the granting of exemptions, reductions, rescheduling or deferrals for the payment of the judicial fees provided by law;

b) defense and free assistance through a lawyer appointed by the bar;

c) any other modalities foreseen by law.

(3) Judicial assistance may be granted at any time during the trial, in whole or in part.

(4) Legal entities may benefit from facilities in the form of discounts, staggered payments or deferrals for the payment of stamp duty fees due for actions and applications submitted to the courts, under the conditions of the special law.
} 


\section{Legislative and jurisprudential guidelines concerning public judicial aid}

\section{The C.C.R. Jurisprudence relevant in the matter}

The Emergency Government Ordinance O.U.G. number 51/2008 formed, repeatedly, the object of the constitutionality control ${ }^{22}$, the Constitutional Court arguing that the Ordinance does not contain regulations contrary to the principle of equality of rights, free access to justice, the right of parties to a fair trial, and the right to petition.

In terms of criticism of extrinsic unconstitutionality, the Court stated that the Emergency Government Ordinance O.U.G. number 51/2008 meets the requirements provided by article 115 of the Constitution referring to legislative delegation ${ }^{23}$.

With reference to the intrinsic unconstitutionality criticisms, in relation to the aspects of the above-mentioned regulation, we observe the following:

With regard to the purpose of the regulation, the Court notes that the by regulating the legal framework of public judicial assistance it aimed to ensure the effectiveness of the right of access to justice, by establishing minimal and reasonable conditions ${ }^{24}$,

22 The Court delivered not less than 106 decisions of rejection of the exception of unconstitutionality of the various legal provisions in the Emergency Government Ordinance O.U.G. number 51/2008, information taken over by consulting the site https://lege5.ro/Gratuit/geytsnrvga/ordonanta-de-urgenta-nr-51-2008-privindajutorul-public-judiciar-in-materie-civila.

${ }^{23}$ With Decision number 374/2014 - published in the Official Gazette of Romania, Part I, number 594 of August 8, 2014 , the court of constitutional contentious found that for the issue of an emergency ordinance is necessary the existence of a objective, measurable state of affairs, independent of the government's will, which jeopardizes a public interest. The Court refers to Decision number 255 of May 11, 2005, published in the Official Gazette of Romania, Part I, number 511 of June 16, 2005, and Decision number 1.008 of July 7, 2009, published in the Official Gazette of Romania, Part I, number 507 of July 23, 2009, through which it retained the implications of the terminological difference between the notion of "exceptional case", used in the conception of article 114 paragraph (4) in the Constitution before revision, and the one of "extraordinary situation", showing that, although the difference between the two terms, from the point of view of the degree of deviation from usual or common which they give expression, is obvious, the same legislator felt the need to shelter it from any interpretation that would minimize such a difference, by adding the expression "whose regulation cannot be postponed", consecrated, thus, in terminis the imperative of emergency of the regulation (paragraph 13)

The court notices that the Government motivated the emergency as being determined by:

- the obligation of transposing the Directive of the Council of European Union 2003/8/CE concerning the improvement of the access to justice in the case of cross-border litigations, through the establishment of common minimum rules on the judicial assistance granted in these categories of cases;

- the minimum standards so that the system of judicial assistance can be considered as ensuring effective access to justice for the citizens of the Member States of the European Union, and the adoption of these standards in the legislative framework requires the creation of at least identical conditions at internal level, so as not to lead to discrimination between its own nationals and nationals of other Member States or persons having their normal place of residence or residence on the territory of a Member State and who would seek legal assistance before courts or other authorities with Romanian jurisdiction;

- by the fact that access to justice - an expression of the democratic principles in a rule of law state with the supremacy of law - must be effective and the costs of a judicial procedure should not be a hindrance in trying to appeal to justice for the realization or defense of a right, justifying, under certain circumstances and conditions, State support from public financial resources (paragraph 15).

${ }^{24}$ With Decision number 264 of February 24, 2009, published in the Official Gazette of Romania, Part I, number 198 of March 30, 2009, that the establishment of certain limits and conditions regarding the granting of public judicial assistance was determined by the possibility of providing the public financial resources necessary for the granting of the aid, by the achievement of a fair distribution of the aid in the forms provided by article 6 of

STUDIES AND ARTICLES 
stating that the access to justice is not an absolute right, but can be limited by certain conditions of form and substance imposed by the legislator, by reference to the provisions of article 21 of the Constitution, but these conditions cannot be accepted if they affect the fundamental right in its very substance.

With reference to the extent and scope of the Emergency Government Ordinance O.U.G. number 51/2008, the Court establishes that from the clear elaboration of the text of article 4 it can be deducted, without any doubt, that in no case can a legal person be the beneficiary of the aid, that the legal provisions according to which only natural persons may apply for public judicial assistance, represent the option of the Romanian legislator, in accordance with the transposition of the provisions of the Directive of the Council of the European Union Directive in internal law by adopting the Emergency Government Ordinance number 51/2008 concerning public judicial assistance in civil matter.

The Court appreciates that the alleged discrimination between the category of natural persons and that of legal persons that article 4 of the Emergency Government Ordinance number $51 / 2008$ operates, by excluding the last categories of persons from the benefit of the public judicial assistance, cannot be retained, since "the discrimination is the result of a different legal treatment applicable to the same category of subjects of law or situations that are not objectively and reasonably distinct. Even if they are parties to a dispute, legal and natural persons cannot be compared nu se pot in terms of the legal situation in which they are. On the other hand, article 4 of the Constitution, defining the criteria of discrimination, including wealth, refers to the citizens of Romania, that is to the category of natural, not legal persons. Therefore, the rationale of the entire normative act being criticized is to facilitate the access to justice for the citizens of the Member States of the European Union for the protection of their legitimate rights, freedoms and interests" 25 .

The constitutional court - through Decision number $428 / 2018^{26}$, notes that no new elements intervened, which would lead to a reconsideration of jurisprudence in the matter ${ }^{27}$ and also refers the provisions of the European Court of Human Rights which, in its jurisprudence, highlighted that the provisions of the Convention for the defence of human rights and fundamental freedoms does not oblige the granting of legal aid in all appeals in civil matters (the Decision of February 26, 2002, delivered in the case Essaadi vs. France, paragraph 30).

\footnotetext{
the Emergency Ordinance, by the prevention from the abusive exercise of the the request for assistance and prejudice to other categories of individuals who would be in need of State support and would ask for it, without thus limiting the actual access to justice.

${ }_{25}$ Decision number 263 of February 24, 2009, published in the Official Gazette of Romania, Part I, nr. 170 of March 18, 2009; Decision number 1.098 of September 21, 2010, published in the Official Gazette of Romania, Part I, nr. 753 of November 11, 2010.

${ }^{26}$ Published in the Official Gazette of Romania, Part I, nr. 778 of September 11, 2018.

27 Decision number 749 of December 16, 2014, published in the Official Gazette of Romania, Part I, nr. 122 of February 17, 2015, or Decision number 671 of November 17, 2016, published in the Official Gazette of Romania, Part I, nr. 113 of February 10, 2017.
} 


\section{Legislative and jurisprudential guidelines concerning public judicial aid}

But it shows that, based on article 42 paragraph (2)-(4) in the Emergency Government Ordinance number 80/2013, in the case of legal persons the court can grant, on request, facilities in the form of reductions, rescheduling or deferral for the payment of stamp duty fees due for actions and requests filed with the courts, under the express and limitative conditions provided by law, and exceptionally, the court may grant to legal entities reductions, rescheduling or deferrals for the payment of judicial stamp duties in other cases in which it considers, in relation to the data regarding the economic and financial situation of the legal person, that the payment of the stamp duty at the amount due would be likely to significantly affect the current activity of the legal person. Thus, legal persons cannot benefit from the exemption of stamp duty, such as the natural persons, but from other legal facilities, which consist in the reduction of the amount of the stamp duty, the staggering or postponing of its payment. This legislative measure represents, however, the legislator's option, being compliant with the provisions of the fundamental Law".

With reference to the elaboration of article 6 of the Emergency Government Ordinance O.U.G. number 51/2008 - that generated the non-unitary judicial practice referring to the form of exemption/reduction/postponement/scaling the payment of the bail, the Constitutional Court holds that "it cannot analyse a text of law in the perspective of what it does not foresee in terminis, namely the absence of regulation of the bail among the forms of public judicial assistance, nor by a comparative examination of the legislation in a given matter, reported at different moments in time. Thus conceived, the claims of unconstitutionality, which tend to complement the legally criticized text, do not have the nature of genuine criticism of unconstitutionality that the Constitutional Court should be competent to examine".

With Decision number 502/2014 (paragraphs 18-21), with reference to the criticism of unconstitutionality concerning the absence of the regulation of the bail among the forms of public judicial assistance, especially in the context in which it was present in the previous legislation in the matter, being provided for by article 75 paragraph 1 of the Code of civil procedure, at present abrogated through the provisions of article 53 of the criticized normative act, the Court -referring to its constant jurisprudence ${ }^{28}$, stated that it aims, in reality, a legislative omission, so it is not competent to resolve exceptions of unconstitutionality regarding legislative gaps or, in the case of legal regulations that is said to be incomplete or unsatisfyingly elaborated, given that it would suppose an immediate intervention in the legislative activity. Distinctly, the Court notes that, in reality, the criticism of unconstitutionality regarding alleged discrimination between Romanian citizens and citizens of other European Union Member States as regards the granting of bail reliefs, starts from a wrong premise, since the hypothesis of the text at

\footnotetext{
${ }^{28}$ Decision number 159 of November 10, 1998, published in the Official Gazette of Romania, Part I, number 51 of February 4, 1999, Decision number 924 of June 23, 2009, published by the Official Gazette of Romania, Part I, number 531 of July 31, 2009, and Decision number 895 of July 6, 2010, published in the Official Gazette of Romania, Part I, number 561 of August 10, 2010.
}

STUDIES AND ARTICLES 
point $\mathrm{C}$ letter e) from the annex to the Government Emergency Ordinance number $51 / 2008$ addresses requests for judicial assistance in another Member State of the European Union. Also, the Court noted that, as it results from the preamble to the Ordinance, Romania was obliged to transpose the Directive of the European Union Council 2003/8 /EC concerning the improvement of the access to justice in cross-border disputes, by establishing common minimum rules on judicial assistance in these categories of cases. Thus, the legislator took into account that the directive provides minimum standards so that the system of judicial assistance can be considered as ensuring effective access to justice for the citizens of the States Members of the European Union, while the processing of these standards on a legislative level pre-supposes the creation of conditions at least identical internally, so as not to give rise to discrimination between their own nationals and the nationals of other Member States or with persons having their normal domicile or residence on the territory of a Member State.

The criticism of unconstitutionality brought to the legal provisions establishing the conditions to be fulfilled for the granting of the aid (article 8 and article 8/1) and the methods of granting them (article 7) were also rejected as unfounded.

With Decision number 773/2018 - published in the Official Gazette of Romania, Part I, number 487 of June 14, 2019, the Court - referring to the the dissatisfaction of the author of the objection of unconstitutionality with the limit set by the legislator regarding the granting of public judicial assistance, respectively the fact that it is not correlated with the the minimum wage on the economy, shows that, in its jurisprudence ${ }^{29}$, noted that these aspects are based on the choice of the legislator, who establishes both the sphere of the persons entitled to request state support and the criteria according to which the public judicial assistance in civil matters is granted and reminded that with the Decision of June 19, 2001, delivered in the Case Kreuz against Poland, paragraph 59, the European Court of Human Rights has held that the actual right of access to a court does not mean, however, an unconditional right to obtain free legal assistance from the State in civil matters nor the right to a free procedure in this matter (paragraph 24, 25).

The Court subjected to constitutional control also the criticisms made by the authors of the many exceptions of unconstitutionality that concerned the provisions of the Emergency Government Ordinance OUG number 51/2008 referring to the extinction of public judicial assistance (article 10$)^{30}$, those concerning the procedure of

\footnotetext{
${ }^{29}$ Decision number 713 of October 27, 2015, published in the Official Gazette of Romania, Part I, number 955 of December 23, 2015, paragraph 17; Decision number 100 of February 25, 2016, published in the Official Gazette of Romania, Part I, number 315 of April 25, 2016, paragraph 15, or Decision number 595 of September 26, 2017, published in the Official Gazette of Romania, Part I, number 148 of February 16, 2018, paragraphs 25 and 26.

${ }^{30}$ Decision number 777/2018 - published in the Official Gazette of Romania, Part I, number 474 of June 11, 2019; Decision number 845/2018 - published in the Official Gazette of Romania, Part I, number 209 of March
}

CONSTITUTIONAL LAW REVIEW 


\section{Legislative and jurisprudential guidelines concerning public judicial aid}

granting public judicial assistance (articles 11-17), respectively the effects of the request (articles 18-19).

We note the analysis carried out by the constitutional litigation court regarding the alleged unconstitutionality of the provisions of article 14 paragraph (1), article 15 and article 19 paragraph 2 in the Emergency Government Ordinance O.U.G. number 51/2008.

With Decision number $485 / 2016^{31}$, the Court retained that, given that the public judicial assistance in civil matters is granted by the state, it is natural that the latter establishes certain conditions, as well as a procedure to follow in order to grant the said assistance. Therefore, the Court found that the provision of the data and documents referred to in article 14 paragraph (1) in the criticized normative act was imposed in the purpose of ensuring the free access of a wider sphere of persons to public judicial assistance and a higher transparency in granting this assistance, as well as for a better administration of the funds having this destination (paragraph 19).

With Decision number $118 / 2017^{32}$, the Court - reiterating the facts established by Decision number $385 / 2011^{33}$, found that, the regulation of article 15 in Emergency Government Ordinance O.U.G. number 51/2008 (ordering that against the decision rejecting the application for public judicial assistance the interested party may apply for a review within 5 days from the date of communication of the conclusion, and the request for reconsideration is settled in the council chamber by another jury) is contrary to the provisions of the Fundamental Law. The Court has held that the examination of the application for the granting of public judicial assistance does not concern the merits of the case and does not necessarily involve contradictory debates. Through this regulation, the legislator took into account the institution of a simple and operative procedure to resolve this request, so that for reasons of celerity the judging in the council chamber, without citing the parties, and the inexistence of the the appeal to a higher court are justified. At the same time, in solving the request, it not necessary to administer all the probation means regulated by the Code of civil procedure, because judging is based on objective criteria that can be substantiated by writings. The fact that the examination of the reexamination request is made by the magistrates of the same court does not prejudice the right to an impartial tribunal and the right to defense. The presumption of impartiality and independence of the judges cannot be eliminated by the fact that they carry out their activity at this court as well as their colleagues who have solved the request for public judicial assistance. On the other hand, the settlement of the re-examination request is based on objective criteria and requires the verification of certain documents from which it should result the material status of the applicant and his / her family (paragraph 17).

\footnotetext{
15, 2019; Decision number 428/2018 - published in the Official Gazette of Romania, Part I, number 778 din of September 11, 2018.

${ }^{31}$ Published in the Official Gazette of Romania, Part I, number 922 of November 16, 2016.

32 Published in the Official Gazette of Romania, Part I, number 538 of July 10, 2017.

${ }^{3}$ Published in the Official Gazette of Romania, Part I, number 431 of June 21, 2011.
} 
With Decision number $757 / 2010^{34}$, with reference to the provisions of article 19 paragraph (2) of the Emergency Government Ordinance number 51/2008 ${ }^{35}$, the Court finds that both the non-diligent behaviour during the process that caused the loss of the process, and the abusive character of the action exercised by the person who benefited from the public judicial assistance, found by court order, constitute in expressions of the same procedural fault of the said person. However, for the valorization of legitimate rights and interests, the parties must act in good faith and not in an abusive, baffling, hostile way for the adverse parties or for the court. As such, the Court notes that the criticism of the author of the exception, according to which sanctioning the litigants for not observing the legal norms would prevent the free access to justice cannot be admitted, the guarantee instituted by article 21 of the Constitution operating only in the situation in which the right deducted to trial is realized in the purpose for which the law recognized it.

Also, the Court The Court notes that the criticized law does not create inequalities or discriminations between citizens or categories of persons, but merely provide for the obligation of the party who has received public judicial aid to repay, in whole or in part, the expenses advanced by the State, in the case of non-diligent or in bad faith exercise of procedural rights, which corresponds to the exigencies of article 57 of the Constitution, that institutes citizens' fundamental duty to exercise the constitutional rights and freedoms in good faith, without violation of the rights and freedoms of others.

\section{Instead of conclusions}

Through the present material we did not propose to achieve an exhaustive analysis of the public judicial assistance institution - an analysis that we consider it would not be possible within the structure of an article, instead we sought to highlight some of the doctrinal and jurisprudential divergences generated by the application of the Emergency Government Ordinance O.U.G. number 51/20008, respectively the modality in which the constitutional contentious court stated with reference to the conformity of the regulation mentioned with the dispositions of the fundamental Law.

\footnotetext{
${ }^{34}$ Published in the Official Gazette of Romania, Part I, number 508 of July 21, 2010.

${ }^{35}$ Article 19 paragraph (2): "But the court can dispose, together with the solution of the case, the resides in obliging the party that benefited from public judicial assistance to return, in full or in in part, the expenses advanced by the state, if through the non-diligent behaviour during the trial that caused the loss of the trial or if through court order it was found that the action was exercised abusively."
} 